\title{
REVERSE PAYMENT PATENT SETTLEMENTS IN THE PHARMACEUTICAL SECTOR AND COMPETITION LAW - DO LUNDBECK AND ACTAVIS HELP TO BRIDGE THE VIEWS ACROSS THE ATLANTIC REGARDING THE DELAYED MARKET ENTRY OF CHEAPER, GENERIC MEDICINES?
}

\author{
Pawan Dutt \& Tanel Kerikmäe ${ }^{1}$ \\ Tallinn Law School, Faculty of Social Sciences, \\ Tallinn University of Technology, Estonia \\ email: pawan.dutt@ttu.ee, tanel.kerikmae@ttu.ee
}

DUTT, Pawan; KERIKMÄE, Tanel. Reverse Payment Patent Settlements in the Pharmaceutical Sector and Competition Law - Do Lundbeck and Actavis help to bridge the views across the Atlantic regarding the delayed market entry of cheaper, generic medicines? International and Comparative Law Review, 2013, Vol. 13., No. 1, pp. 23-38. DOI: 10.1515/iclr-2016-0056.

\begin{abstract}
Competition law and Intellectual Property law are remarkably divergent in scope and thus make for uneasy bedfellows. Although they both purport to help the consumer, their effects on the common market can be strikingly different. Recent decisions in the European Union and the United States of America have brought into focus the role of reverse payment patent settlement agreements. These agreements are generally of a commercial nature, and are agreements to settle actual or potential disputes which are related to patents. The questions which are sought by the parties to mutually settle range from infringement of a patent or the validity of a patent. When such a settlement agreement between a patent holder (in this instance the originator company) and a patent challenger (being a generic company) involves a value transfer from the originator to the generic company, coupled with a provision to limit or restrict the generic company's ability to market its own product on the market, then certain interesting areas of conflict tend to come forward. The question arises whether this is simply a case of a company paying off its competitors to stay out of its market and delay the entry of cheaper, generic medicines, and is thus purely

1 Pawan Dutt is a Lecturer at Chair of Law and Technology, Tallinn Law School, Faculty of Social Sciences, Tallinn University of Technology, Estonia. Email: pawan.dutt@ttu.ee.

Tanel Kerikmäe is a professor and head of the Jean Monnet Chair of European Law, Tallinn Law School, Faculty of Social Sciences, Tallinn University of Technology, Estonia. Email: tanel. kerikmae@ttu.ee.
\end{abstract}


anticompetitive and harmful to consumers? Or whether the right to settle a patent dispute within the scope of patent laws is something which is outside the domain of Competition law? The European Commission and the Federal Trade Commission have displayed similar levels of distrust towards such commercial settlement agreements, and now the United States Supreme Court has weighed in with its own opinion. It remains to be seen how this matter will develop further in the courtrooms on both sides of the Atlantic.

Keywords: competition, intellectual property, pharmaceutical industry, reverse payment patent, European Union, Unites States.

\section{Introduction}

An Intellectual Property Right (IPR), be it a trade mark, patent, copyright, design, or any other legally protected right, is by its very nature, a monopolistic venture. Hence its grant by the concerned authorities inevitably raises the issue of contravention of Competition laws, since both these streams of law cater to opposing viewpoints. This is essentially due to the inherent nature of an IPR, which grants an artificial protection to companies. This protection, in turn, can potentially furnish the IPR holder with an advantage over its competitors. This advantage can be manifested in different forms, ranging from dominance in a market on the one hand, to even an all encompassing monopoly at the other extreme end. Conversely, Competition law works on two rather lofty premises, namely the promotion of competition between companies on the market and, as far as possible, the enhancement of such competition to its highest possible form. Notwithstanding the above, the inevitable conclusion which arises from an overview of both these extremes is the fact that both, IPRs and Competition law have surprisingly similar aims - enhancement of consumer welfare being foremost. Allocation of resources in an efficient manner is another key consideration, as is the promotion of competition in an effective manner through innovation and investment in product development. ${ }^{2}$

Conflict between IPR and Competition laws could be termed as a recurring problem which is as old as the hills. It has been noted that issues relating to IPR and the regulation of competition between commercial entities tend to lead an uncomfortable co-existence. ${ }^{3}$ However, it is also generally agreed that Competition law should not be used as a bludgeon against IPRs as this can negatively impact incentives for innovation. ${ }^{4}$

2 H.K.S. Schmidt, "The Influence of IP Rights on Product Definition in Competition Law - The Curious Case of Tying" 21(6) International Company and Commercial Law Review 224, at 224 (2010).

3 M. Daniels, "Review of the Book Critical Concepts in Intellectual Property Law - Intellectual Property and Competition" 34(4) European Intellectual Property Review 294-295 (2012).

4 OECD Roundtable on Patents, Innovation and Competition, 2006 at 8, available at http://www. oecd.org/competition/abuse/39888509.pdf (last accessed on 28 August, 2013). 
The US District Court, in one instance, had brought on record an old case dealing with a patent-antitrust conflict which was considered by the English Court of King's Bench in 1602, as the first reported case on the subject (Darcy v. Allein). Since then, it is interesting to note that the issues arising in this field have yet to be resolved in a satisfactory manner or with any touch of lucidity. The US District Court stated further, inter alia, that economic arguments regarding the common goal of the two abovementioned laws notwithstanding, the unfortunate fact still remains that they are judicially divergent. ${ }^{5}$

In the European Union (EU), it has since long been held by the courts that the first holder of an IPR enjoys the right as an owner because the state has granted him such a legal status specifically in relation to his invention. Further, such ownership has nothing to do with the rules relating to Competition law, per se. ${ }^{6}$ However, the provisions of Competition law will apply against the exercise of the above mentioned right if the purpose, effect or any agreement related to or of such a right is inherently anticompetitive in nature. ${ }^{7}$

It is not uncommon for most countries to provide special exceptions to IPRs as a means of protecting them from their prohibiting monopolies, in order to create some semblance of balance between the interests of consumers and the state vis a vis the IPR owners and their perceived rights. Further, the IPRs held by their respective owners are construed in a strict sense and are very often strictly limited to the narrow confines of the grant. Any mischievous attempt to breach the boundaries of the grant is deemed to be a misuse thereof and is treated as being downright illegal in nature or void of effect in the eyes of the law, to say the very least. ${ }^{8}$

It is therefore clear to all that although an exclusive right to exploit an IPR may be legally granted by the state, the implication that this would mean that IPRs are in some way or manner immune from intervention by Competition law authorities is incorrect. However the lines can sometimes appear blurred, to say the very least.

Generally, patents are seen as essential for protecting IPRs of inventors so that they can use their innovations to make profits, and hopefully reinvest their profits and continue to work in their field. Many business experts have spoken about the high risks that product innovation can entail, and the high failure rates that businesses have become accustomed to in this field. Hence the need arises

5 R. August, International Business Law, (Pearson Prentice Hall, 2002) at 507. Footnote 129 therein refers to caselaw SCM Corp. vs. Xerox Corp., District of Connecticut, United States District Court, District of Colombia [1978] Federal Supplement, vol. 463, p. 996 - 997, from which this quote is taken.

6 Case 24/67 Parke, Davis v Probel [1968] E.C.R. 55; [1968] C.M.L.R. 47.

7 Case 144/81 Keurkoop BV v Nancy Kean Gifts BV [1982] E.C.R. 2853 AT 2873; [1983] 2 C.M.L.R. 47.

8 R. August at 507. 
for extraordinary returns to help justify the high investments and commercial risks. ${ }^{9}$ Although a patent is granted for upto twenty years from the date of the first application, the effective period available to a patent holder to commence making a profit is much shorter in duration. This is because the processing of the patent application takes time, and once a patent is granted then to operationalise the manufacture, marketing and sale of that product takes more time.

In the case of pharmaceutical products, once the patent expires then generic copies of the product can be freely sold in the market by the competitors of the patent holder. The other alternative for a generic company is to apply for authorisation from the relevant authorities to legally market the drug, with the strong possibility of risk of ensuing litigation from the patent holder. ${ }^{10}$

Many Small and Medium Enterprises (SMEs) are involved in the pharmaceutical sector worldwide. The use of the Intellectual Property system by SMEs in the pharmaceutical industry depends largely on the business strategy of the company. Other relevant factors are size, ability to generate resources, capacity for innovation, general competitiveness and broad experience in this sector. ${ }^{11}$ Although most operate in their local markets, often the way forward for them is to link up with larger players and enter into the fields of clinical trials or contract manufacturing of pharmaceutical products and related chemical components. This form of outsourcing by the bigger companies helps the SMEs to achieve commercial viability. If and when a SME acquires marketing approval of generic products (from the concerned authorities) then it can increase its product portfolio and grow bigger. ${ }^{12}$ However, most SMEs face difficulties in sustaining their business models, especially since they are vulnerable to attack by the bigger pharmaceutical companies who can afford costly litigation.

It is interesting to note that the European Commission (EC) found in the year 2009 that the effective protection period from the date of launch of the pharmaceutical product to the first generic launch is over 14 years. This is more than what it was in the year 2000, when the figure stood at 10 years. ${ }^{13}$

An interesting area of conflict has been seen recently in the context of patent settlement agreements. These agreements are generally of a commercial nature, and are agreements to settle actual or potential disputes which are related to pat-

9 T. Sichelman, "Taking Commercialisation Seriously" 33(4) European Intellectual Property Review 200-203 at 201 (2011), where the author refers to observations regarding product innovations and the high risks that plague them, made by experts in the field of product development and commercialisation.

10 N. Tuominen, "An IP Perspective on Defensive Patenting Strategies of the EU Pharmaceutical Industry" 34(8) European Intellectual Property Review 541-551 at 546 (2012).

$11 \mathrm{http} / / /$ www.wipo.int/sme/en/documents/ip_pharma.html (last accessed 28 August, 2013).

$12 \mathrm{http}: / /$ www.dnb.co.in/pharmaceutical/smes.asp (last accessed 28 August, 2013).

13 Commission Press Release IP/09/1098 (8 July, 2009) "Antitrust: Shortcomings in Pharmaceutical Sector Require Further Action", available at http://europa.eu/rapid/press-release_IP-09-1098_ en.htm?locale=en (last accessed 28 August, 2013). 
ents. The questions which are sought by the parties to mutually settle range from infringement of a patent or the validity of a patent. These settlement agreements are concluded when a dispute is either brewing, or is being contested within the confines of a national patent office in the form of opposition procedures, or litigated in a courtroom. The key consideration to bear in mind is that no final adjudication has been handed down. The common aim of such a settlement is simply to halt the dispute. ${ }^{14}$

In order to protect their commercial interests, the big pharmaceutical companies who hold patents engage in the practise of "evergreening", in various forms and formats. These are primarily defensive strategies, which can include, interalia, entering into agreements with generic manufacturers in order to secure the postponement of generic market entry. ${ }^{15}$ Thus, when such a settlement agreement between a patent holder (in this instance the originator company) and a patent challenger (being a generic company) involves a value transfer from the originator to the generic company, coupled with a provision to limit or restrict the generic company's ability to market its own product on the market, then certain interesting areas of conflict tend to arise.

To put it in a nutshell, Commission Vice-President Joaquín Almunia, in charge of competition policy, said: "It is unacceptable that a company pays off its competitors to stay out of its market and delay the entry of cheaper medicines. Agreements of this type directly harm patients and national health systems, which are already under tight budgetary constraints. The Commission will not tolerate such anticompetitive practices". ${ }^{16}$

\section{The Lundbeck Case}

The Danish pharmaceutical company Lundbeck held a product patent for the Citalopram molecule, and several related process patents. Citalopram was a blockbuster antidepressant medicine and was the best selling branded product of Lundbeck. After the basic product patent had expired, Lundbeck was left with several related process patents. These however provided a more limited protection from the IPR viewpoint. Thus, legally speaking, producers of cheaper, generic versions of Citalopram now had the opportunity to enter the market and sell their own versions of Citalopram. It is generally acknowledged that competition by generic manufacturers can cause prices of the medicine to reduce in a significant manner (it is estimated by the EC that the entry of generic Citalopram products in the United Kingdom market caused the price of the product

14 Commission, First Report on the Monitoring of Patent Settlements (2010) at 1, available at http://ec.europa.eu/competition/sectors/pharmaceuticals/inquiry/patent_settlements_report1. pdf (last accessed 28 August, 2013).

15 N. Tuominen at 546.

16 Commission Press Release IP/13/563 (19 June, 2013), “Antitrust: Commission Fines Lundbeck and other Pharma Companies for Delaying Market Entry of Generic Medicines", available at http://europa.eu/rapid/press-release_IP-13-563_en.htm (last accessed 28 August, 2013). 
to nosedive by upto 90 percent), thereby causing a huge drop in the profits of the producer of the branded product.

The EC alleges that instead of competing in a free market, however the opposite took place. Lundbeck and the generic producers are accused of entering into a mutual agreement in 2002, whereby the generic manufacturers refrained from entering the market with their generic versions of Citalopram. In return, it is claimed that Lundbeck offered the generic manufacturers substantial payments and other inducements, to the tune of several million Euros. Not only did Lundbeck pay significant lump sums to the generic manufacturers, but it also purchased the stock of generic version of Citalopram from the manufacturers for the sole purpose of destroying these stocks. Thirdly, Lundbeck offered guaranteed profits to the generic manufacturers by way of dubious distribution agreements. By way of such inducements, Lundbeck was able to keep the generic manufacturers out of the market for the duration of the agreements.

The EC conducted wide ranging monitoring exercises from 2008 onwards. Consequent to this, the EC has alleged that the above agreements were, by their nature, very different from other patent dispute settlements. It was unclear as to why generic companies were paid off, and the assumption arose that this was done purely to keep the generic manufacturers out of the market and to reduce competition with respect to this particular drug. Thus the EC held that the above agreements violated Article 101 of the Treaty on the Functioning of the European Union (TFEU), as these were clearly designed to circumvent the prohibition of anticompetitive agreements under the said article.

Accordingly, the EC announced on $19^{\text {th }}$ June, 2013 that it had imposed fines on Lundbeck to the tune of 93.8 million Euros and on the generic manufacturers (namely Alpharma, Merck KGaA/Generics UK, Arrow and Ranbaxy) fines totaling 52.2 million Euros. It should be noted that this is the first time that the EC has imposed such heavy fines in a case like this. The EC is also investigating anti competitive law practices in the context of two other drugs, namely Perindopril and Fentanyl in 2012 and 2013 respectively. ${ }^{17}$

The pharmaceutical sector has been facing close scrutiny from the EC since it is important to the health of Europe's citizens and has a major impact on the finances of governments in the EU. ${ }^{18}$

Inquiries by the EC held over a period of 7 years from 2000 to 2007 in 17 Member States of the European Union (EU) have shown that citizens had to wait for more than 7 months after the expiry of the patent to be able to access cheaper generic versions of those medicines. This added to almost 20 percent in extra spending. Since competition by generic products brings down prices to a substan-

17 Id. at 2.

18 Art.168(1) TFEU provides that "A high level of human health protection shall be ensured in the definition and implementation of all Union policies and activities." 
tial extent (it is estimated by the EC that on an average generic products tend to be 40 percent cheaper just two years after their entry into the market, when compared to the prices of the originator drugs), this is a matter of great relevance to EU consumers in general. It was also unearthed by the EC inquiry that originator companies tend to use a variety of instruments to protect the commercial viability of their pharmaceutical products by barring the entry of generic products into the market for as long a period as is possible. This included dubious settlements between originator and generic companies which caused harm to the interests of consumers. The competitive relationship between originator companies and generic companies lead to delays of entry of generic pharmaceutical products into the market and this in turn denies patients in the EU access to medicines which are of an innovative nature, which are affordable for all and most importantly which ensure safety concerns. The EC was of the view that competition between originator companies and generic companies does not work as well as it should, and it accused originator companies of using several delaying strategies aimed at generic companies such as use of patent clusters (filing thousand plus patent applications for a single medicine), vexatious patent litigation (which can last over three years on an average) or lastly entering into settlement agreements whereby generic entry is restricted and sometimes involve value transfers from the originator to the generic company. Originator companies also tried to delay regulatory approval of generic medicines by the Member States. ${ }^{19}$

\section{Views of the EC}

An important issue that arises from the above is the concern whether the EC's competition department is competent to address problems relating to patents, and in doing so, does the EC run the risk of supplanting itself in the place of the patent office. The EC stresses on the need for innovation and that if an invention matches the patentability criteria then Competition law shall not "second guess". ${ }^{20}$ The EC, for its part, denies any claims of usurpation of powers, and further asserts that it has worked closely with the European Patent Office in this regard However, the EC is clear about its obligation to apply the antitrust rules at its discretion when the misuse of the patent system or other regulatory processes affects competition in the market place. ${ }^{21}$ The EC has also pointed to the various OECD Roundtables on Patents, Innovation and Competition, held in 2006 and 2009 where the issue of the use of patents and their possible negative effects on innovation and competition have been discussed in detail. ${ }^{22}$

19 Commission MEMO/09/321 (8 July, 2009), "Antitrust: shortcomings in pharmaceutical sector require further action - frequently asked questions" at 2, available at http://europa.eu/rapid/ press-release_MEMO-09-321_en.htm (last accessed 28 August, 2013).

20 N. Tuominen at 546, where she also draws reference to Commission, Final Report (2009), p.11, http://ec.europa.eu/competition/sectors/pharmaceuticals/inquiry/staff_working_paper_part1.pdf

21 Commission MEMO/09/321 at 5.

22 See OECD Roundtable on Patents, Innovation and Competition, 2006, available at http://www. oecd.org/competition/abuse/39888509.pdf (last accessed on 28 August, 2013). 
There is no disputing the fact that the EC agrees that parties to a commercial dispute have a legitimate interest in reaching a compromise which would be mutually acceptable. This is desirable since disputes or litigation can be expensive, time consuming and there is always an element of risk when it comes to the aspect of the outcome of the case. Thus settlements are a legitimate route to end a disagreement between private parties. This is also a time saving device for judicial, semi judicial and administrative authorities and has significant positive impacts on the interest of society. ${ }^{23}$

However, some patent settlements in the field of pharmaceuticals are, in the view of the EC, rather problematic when seen through the prism of Competition law. Any agreement between parties to a dispute, which has the effect of delaying the entry of a potentially cheaper generic drug into the market, in return for a value transfer to the generic company by the original patent holder company is especially fraught with dangerous consequences for the state in general and the consumer in particular. Key areas of concern in such agreements are where:

a. the scope of the patent is extended beyond its geographical limits,

b. the restriction extends beyond the legitimate period of protection of the patent,

c. the restriction extends beyond the claims of the granted patent, or

d. the patent holder knows that his invention does not meet the criteria of patentability and has thus been wrongly obtained, or the granting of the patent by the concerned patent office was due to information which was incorrect, misleading or incomplete, yet strives to maintain the status quo.

The EC is of the opinion that settlement agreements containing such provisions would no longer appear to be directly related to the IPR regime, since they can potentially have a very negative effect on the finances of the consumer who pays the price for the delay Of entry into the market of the generic drug, notwithstanding any of the above mentioned benefits to society arising from such an agreement. ${ }^{24}$

Accordingly, the EC has sought to categorise patent settlement agreements on the following basis, namely:

a. whether the agreement foresees a limitation on the ability of the generic company to market its own generic version of the medicine, and

b. b) whether the agreement envisages a value transfer from the originator company to the generic company, in lieu of a settlement. ${ }^{25}$

The EC is of the opinion that a limitation on the entry of a generic company in the market can be effected through the use of non-challenge clauses or

23 Commission, First Report on the Monitoring of Patent Settlements (2010) at para 3.

$24 I d$ at para 4.

$25 I d$ at para 7. 
non-compete clauses in a settlement agreement. Further, a licence granted by the originator company to the generic company can result in partial control of the former over the latter, and thus be restrictive. ${ }^{26}$ Similarly, if the generic company is forced to accept a distribution agreement whereby it is forced to sell the originator company's products alone, or is forced to source its supplies of the active ingredient from the originator company, to the exclusion of all other sources, etc are seen by the EC as some of the potential limitations. ${ }^{27}$ Further, a value transfer from the originator company to the generic company could be in the form of a direct monetary transfer (ostensibly as compensation for the legal costs incurred by the generic company or for the purchase of its stock, but in reality having the odious purpose of paying the generic company for agreeing to delay the launch of its generic product in the market). Similarly, a lucrative distribution / licence agreement could be some of the guises in which value transfers are effected between originator companies and generic companies. ${ }^{28}$

Based on the above categorization criteria, the EC has reached the conclusion that certain types of agreements (namely in the B.II category - which limit the generic entry and foresee a value transfer from the originator to the generic company) are deemed problematic and require closer scrutiny. ${ }^{29}$ However, there is a clear degree of overlap between IPR law and Competition law in the concerns expressed by the EC in the case of even seemingly unproblematic settlements (namely where the settlement which is unrestrictive of the generic entry (deemed A category) nonetheless caused a delay in the generic entry due to unilateral conduct of the originator company, ${ }^{30}$ or a settlement which although limiting the generic entry but not including any value transfer from the originator to the generic company (deemed as B.I category) nonetheless provides for a settlement which is outside the exclusionary zone of the patent or which includes patents for which the patent holder knows that it does not meet the patentability criteria). ${ }^{31}$ In cases such as these, the EC views such agreements as problematic from the Competition law perspective, although the author feels that such issues should rightly be addressed by laws concerning IPR, rather than Article 101/102 of the TFEU.

The author also finds it very worrying when the EC is quick to typecast private business settlement agreements (of the A category) as "concluded on a

26 However see also Commission, Third Report on the Monitoring of Patent Settlements (2012) at para 8, where the EC concedes that an exception would apply in case of royalty free licenses that allow generic companies to immediately launch their generic product without any constraints related to quantities, composition, pricing, etc. It is available at

http://ec.europa.eu/competition/sectors/pharmaceuticals/inquiry/patent_settlements_report3_ en.pdf (last accessed on 28 August, 2013).

27 Commission, First Report on the Monitoring of Patent Settlements (2010) at para 8.

28 Id. at para 9.

$291 d$. at para 14.

$301 d$. at para 12.

31 1d. at para 13.

(C) Palacký University Olomouc, Czech Republic, 2013.

ISSN 1213-8770 (print), ISSN: 2464-6601 (online). 
walk away-basis" (where litigation is presumed by the EC to be a waste of time and resources of the parties concerned $)^{32}$ or B.1 category agreements as those where the parties are deemed to have assessed that the originator company had a "strong case". ${ }^{33}$ What the author fears is that such typecasting by the EC often overlooks the hard, commercial realities faced by businesses in today's market. Another indicator of the EC mindset can be seen from the fact that after it had carried out a sector inquiry on the Pharmaceutical Sector in 2009 and had also conducted several monitoring reports of patent settlements, it is now keen to extend enquiries in the context of technology licensing, all in the name of securing the ideals of innovation and competition. Thus the draft Technology Transfer Guidelines look more deeply at the anti-competitive outcomes of "pay-fordelay" or "reverse payment" settlement agreements and no-challenge clauses in the context of such settlement agreements. One question that arises is as to how the EC will judge whether the licensor knew or could reasonably be expected to know that his invention did not justify being conferred intellectual property law protection. ${ }^{34}$

The first EC patent monitoring exercise covered the period of 1 July 2008 until 31 December, 2009. ${ }^{35}$ The second monitoring exercise covered the period of 1 January, 2010 until 31 December, 2010 (it added a significant number of companies when compared with the first report, and also included information found in the specialised press on the conclusion of settlement agreements). ${ }^{36}$ The third monitoring exercise covered the period from 1 January, 2011 to 31 December, $2011 .^{37}$

Data collected by the EC in the course of the above exercises shows that although there has been an increase in number of payments connected to B.II settlements, the overall picture shows that the percentage of B.II settlements in general have significantly decreased since the sector inquiry. ${ }^{38}$ So although the implication is that this is due to an increased awareness of companies and their legal advisors to the inquiries conducted by the EC into the legality of such settlements from the point of view of Article 101 of TFEU, ${ }^{39}$ the EC however is quick to use statistics to show that its actions have not hindered companies from concluding patent settlement agreements in general (which have substantially

$321 d$. at para 27.

$331 d$ at para 31.

34 P. Alexiadis, "European Commission Proposes Stricter EU Antitrust Rules on Technology Transfer" 35(7) European Intellectual Property Review 415-419 at 418 (2013).

35 Commission, First Report on the Monitoring of Patent Settlements (2010) at para 36.

36 Commission, Second Report on the Monitoring of Patent Settlements (2011) at para 18, available at http://ec.europa.eu/competition/sectors/pharmaceuticals/inquiry/patent_settlements_report2. pdf (last accessed 28 August, 2013).

37 Commission, Third Report on the Monitoring of Patent Settlements (2012) at para 16.

38 Id at para 45.

39 As evidenced in Commission, Second Report on the Monitoring of Patent Settlements (2011) at para 35 
risen to 120 in the year 2011 compared to the average of 24 per year between the years 2000 - 2008). This is used by the EC as a counter reply to the doomsayers who suggested that the hard approach adopted by the EC in this regard would force companies to litigate each patent dispute until its bitter end. Further the EC also states that almost 89 percent of patent settlement agreements fall into the $\mathrm{A}$ and B.I category which are typically considered by the EC to be "unproblematic" from the viewpoint of Competition law. ${ }^{40}$

So this is how things stand as of $19^{\text {th }}$ June, 2013 in the EU with regard to Patent Settlements in the Pharmaceutical Sector and Competition Law. It remains to be seen what legal resources will Lundbeck resort to, in order to challenge this order of the EC..$^{41}$ By a strange coincidence, two days earlier (on the $17^{\text {th }}$ June, 2013), the United States Supreme Court (SC) dealt with a matter which bore remarkable similarities to the above mentioned Lundbeck case.

\section{Parallels with Actavis Case}

In Federal Trade Commission vs. Actavis, Inc. and others ${ }^{42}$ the SC dealt with an issue arising under the Hatch-Waxman Act of 1984. Solvay Pharmaceuticals obtained a patent for its branded pharmaceutical product AndroGel. 2 generic manufactures, Actavis and Paddock, filed applications before the US Food and Drug Administration (FDA) under the Hatch-Waxman Act for generic drugs modeled after AndroGel. Further, they certified that Solvay's patent was invalid and that their generic copies did not infringe Solvay's patent. Solvay immediately sued Actavis and Paddock for infringement of its patent.

The FDA eventually approved the generic product of Actavis. However, instead of introducing its generic version to the market, Actavis took the unusual step of entering into a reverse payment settlement agreement with Solvay. Under the terms of this agreement, Actavis undertook not to bring its generic product to the market for a specified number of years in exchange for millions of dollars from Solvay. Paddock and another generic manufacturer made similar agreements with Solvay subsequently.

The Federal Trade Commission (FTC) sued the parties, alleging that this was an unlawful agreement to abandon legitimate patent challenges, refraining from launching cheap generic drugs in the Market and actively sharing Solvay's monopoly profits. The FTC has for long viewed such settlement agreements (where the plaintiff agrees to end the litigation by paying the defendant millions to stay out of its market, even though there is no monetary claim sought by the

40 Commission, Third Report on the Monitoring of Patent Settlements (2012) at para 50.

41 J. Kanter, "Europe Fines Drug Companies for Delaying Generics" The New York Times, 19 June, 2013, available at http://www.nytimes.com/2013/06/20/business/global/eu-fines-drugcompanies-for-delaying-generics.html (last accessed 28 August, 2013).

42570 U.S. [2013], United States Supreme Court. 
defendant against the plaintiff) as unusual and having significant adverse effects on competition. ${ }^{43}$

The District Court dismissed the complaint, in appeal the Eleventh Circuit concluded that as long as the anticompetitive effects of an agreement settlement fell within the scope of the exclusionary potential of a patent, the settlement was immune to Competition law. It further held that settlement of legal disputes was a matter of public policy, and courts could not require parties to litigate merely to avoid liability under antitrust laws.

The FTC appealed to the SC which held that the Eleventh Circuit had erred and remanded the matter back to the District Court. It was held by a majority of 5-3 in the SC that reverse payment patent settlement agreements are not immune from antitrust attack. Further, such settlements are unusual and can have a significant adverse effect on competition. The SC held as follows ${ }^{44}$ :

a. There exists prior case law in the form of precedents which clearly stipulate that the right to exclude granted by a patent is limited by concerns regarding the antitrust legality.

b. There is the potential that such patent settlement agreements have for genuine adverse effects on competition.

c. There might be pro-competitive benefits under such agreements, but that possibility does not justify dismissing the objections of the FTC.

d. The size of the payment to the generic challenger is a strong indicator of potential harm due to exercise of a monopoly, and the likely possibility of higher than usual prices payable by the consumer.

e. An unexplained large reverse payment itself would normally suggest that there are serious doubts in the mind of the patentee regarding its patent, thus enabling a court to determine the outcome without going into detail with regard to the question of validity of the patent.

f. The parties to the dispute can still settle their disagreements without unjustifiably large reverse payments.

g. The reverse payment settlement agreement is not presumptively unlawful (as suggested by the FTC). Rather the "Rule of Reason" should be applied to such agreements in order to study their factual details in a close manner, bearing in mind the size, scale in relation to the payor's anticipated future litigation costs, payment in lieu of other

43 R.H. Stern, "Antitrust Legality of Reverse Payments from Patentees to Accused Infringers Upheld: In re Ciprofloxacin Hydrochloride Antitrust Litigation" 31(2) European Intellectual Property Review 101-102 (2009), where the case In re Ciprofloxacin Hydrochloride Antitrust Litigation 544 F.3d 1323 (Fed. Cir. 2008) dealing with reverse payment settlement agreements is discussed and the question is raised whether the public interest in clearing the market of spurious patents should override the patentee's rational self interest in maximising its financial return by prudent settlement?

44 Opinion of the Supreme Court at 14 and onwards. 
services and the need to independently verify these, and lack of convincing justification.

\section{Points Raised by the Dissenting Judges in the Above Case}

Although the dissenting opinion voiced by Chief Justice Roberts, together with Justice Scalia and Justice Thomas raises to the fore issues from the US legal point of view, there are certain aspects of their comments which resonate with all those who specialize in intellectual property laws. The long held position that a patent carves out something of an exception when it relates to the question of applicability of Competition (or antitrust) laws, appears to be under attack. The difficulty arises in showing how a patent strategy can be deemed to be abusive without allowing Competition law rules to interfere with the rationale of the patent law regime itself. ${ }^{45}$ Since the scope of the patent forms the zone within which the patent holder has complete freedom to operate without having to face any risk of anti competition liability, it necessarily leads to the converse being true - namely that any action by a patent holder which goes beyond the monopoly powers conferred by his patent will subject him to anti competition scrutiny. The only two exceptions are when the settlement of a sham litigation is entered into between the opposing parties, or when the litigation involves a patent obtained from the patent office in a fraudulent manner. ${ }^{46}$

Since a patent grants a limited monopoly, the obvious defense of a patent holder in any anti competition suit is to contend that his patent allows him to engage in conduct of a nature which would be tantamount to violation of the Competition laws. ${ }^{47} \mathrm{~A}$ court cannot simply ignore the lawfully granted patent and engage in an anti competition analysis of the settlement while ignoring the basic question regarding the validity of the patent. The patent holder is merely exercising the rights which were granted to him by the Government through its patent office. ${ }^{48}$ The question that should arise is whether the patent is either valid or invalid..$^{49}$ It cannot possibly be both at the same time. Then why should the courts interfere and thereby unsettle the established relationship between patent law and Competition law?

Further, when the majority in the SC suggested that a reverse payment agreement is unusual because a generic company with no claim for damages seeks (and obtains) money from the patent holder in return for staying away from the patent holder's market, the fact which is ignored by the SC is that the generic

45 Dissenting opinion of the Supreme Court at 1.

$46 \quad I d$ at 3.

$47 \mathrm{~N}$. Tuominen at 550.

48 Dissenting opinion of the Supreme Court at 5.

49 Id at 13

50 Id at 9

(C) Palacký University Olomouc, Czech Republic, 2013.

ISSN 1213-8770 (print), ISSN: 2464-6601 (online). 
company is suing for the right to use and market the valuable intellectual property of the patent holder. ${ }^{51}$

The issue whether a patent is valid or not is again something for the patent law to settle, and it cannot be settled by Competition law. This of course is hotly contested by the "fierce advocates of anti trust law" who would rather lead the public to believe IPR has become increasingly monopolistic and that this issue has increased in scale to such an extent that it needs to be curtailed. ${ }^{52}$

Another key point is that if the parties settle a patent dispute, and then face the prospect of litigating the same issue, namely that of the validity of the patent, as part of a defense against a suit for anti competition malpractices, then the parties would be discouraged to settle the dispute in the first place. ${ }^{53}$ Since litigation costs can be very high in patent disputes (as the dissenting opinion suggests this sum can be in the millions of US Dollars per suit, according to empirical studies on this subject ${ }^{54}$ ), the complexity and expensiveness of patent disputes cannot be ignored by a court while considering the legality of the settlement dispute. Only a patent holder should have the right to decide how he wishes to settle his patent dispute, as long as he works within the scope of his patent, bearing in mind his own business needs. It would be very difficult to ascertain why a patent holder actually agreed to enter into a patent settlement, and if the court wished to deduce the patent holder's opinions about the strength of its own patent, then the court might need to access documents which constitute privileged communication between the patent holder and its patent lawyers. ${ }^{55}$

Further, such a patent settlement agreement between the patent holder and a bunch of generic companies would not prevent other generic companies to try and enter the market. Notwithstanding the particular US specific issues listed under the Hatch-Waxman Act, there are serious implications of this distinct possibility arising in the EU context. As the dissenting judges have stated, any patent holder who is perceived as amenable to settling a patent dispute by offering large sums of money to his generic rivals, merely because he believes that his patent is weak, would be opening the floodgates to litigation by all and sundry, with other generic manufacturers hoping to cash in and make a fast buck. Thus, such a policy of a patent holder would be self defeating, to say the very least. ${ }^{56}$

51 Id at 10.

52 P. S. Morris, "Review of the book Creation Without Restraint: Promoting Liberty and Rivalry in Innovation" 34(9) European Intellectual Property Review 645-647 at 645 (2012).

53 Dissenting opinion of the Supreme Court at 11.

54 M.R. Herman, "Notes, the Stay Dilemma: Examining Brand and Generic Incentives for Delaying the Resolution of Pharmaceutical Patent Litigation" 111:1788 Columbia Law Review 1788 - 1832 at 1795. It is available at http://www.columbialawreview.org/wp-content/uploads/2012/07/111-8_ Herman.pdf (last accessed 28 August, 2013).

55 Dissenting opinion of Supreme Court at 13.

56 Id at 16. 
Lastly, the dissenting opinion deals with the issue of generic companies and the commercial decisions which encourage them to challenge pharmaceutical patents. Generic companies tend to be shrewd business operators who carefully weigh the pros and cons before entering into expensive patent litigation, and the prospect of removing settlements from the negotiating table, or the limitation thereof would curtail the behavior of a generic company, both within and outside the court room. ${ }^{57}$ This would especially be true in the case of SMEs who have limited legal budgets to begin with.

Hence the worry that such actions by the Competition authorities and courts would cause high uncertainty and have a chilling effect on patent disputes.

\section{Conclusion}

It remains to be seen as to how the issues studied in this article by the author will unfold in the future. The approaches adopted by the EC and the FTC in their respective jurisdictions so far have been quite similar. However, potential divergence of approach may be noticed soon, considering that in the Lundbeck case the parties have stated their intention to take the EC to court for a judicial scrutiny. Further, the FTC v Actavis decision has been remanded to the lower courts and will eventually come up for appeal. At the same time, similar settlement agreements entered into between other pharmaceutical companies will be reviewed by the respective Competition law authorities and this will no doubt unearth more interesting views on such cases.

Notwithstanding the outcomes of the above listed issues, the following are the main questions that will continue to be-devil parties to a dispute of such a nature:

a. What is the value of the patent claims that have been granted protection by the patent office? Can the patent office be left out of the discussion regarding the validity of the patent granted by it, when this question comes up for appraisal before the EC on the grounds of anti competitiveness?

b. Should the parties to a dispute be forced to justify a patent settlement agreement when it makes commercial sense and is within the obvious scope of the patent law, and when the negative effects of such an agreement on the consumers are not quantifiable?

c. Should the EC have the power to indulge in a "fishing expedition" and trawl through vast amounts of paperwork (including privileged communication between patent attorneys and their clients) in order to prove that the parties to the dispute knew (or should have known) that their IPR is weak or unsubstantiated. Can such a finding by the EC

57 Id at 17.

(c) Palacký University Olomouc, Czech Republic, 2013. ISSN 1213-8770 (print), ISSN: 2464-6601 (online). 
ICLR, 2013, Vol. 13, No. 1.

erode the trust of the patent holders in the ability of the state's patent office.

d. Is it better to fight out a patent dispute to its logical end in the courtrooms (and exhaust all options to appeal), rather than to settle the dispute and face the risk of an inquiry by the EC (an enquiry which would necessarily ask the same question - is the patent valid in the first place, and if the answer is yes then why did the patent holder stoop to settle despite holding a higher ground and potentially a "winning hand").

Thus one can see that the question of supremacy of one set of contradictory laws over another is far from settled and will continue to baffle the experts for years to come. 